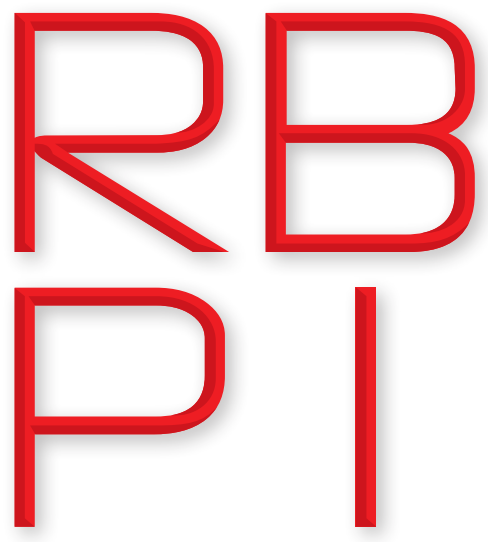

Revista Brasileira de Política Internacional ISSN 1983-3121

http://www.rbpi.info

\section{Manuela Picq}

Universidad San Francisco de Quito, Departamento de Relaciones Internacionales, Quito, Ecuador (manuelapicq@me.com).

\title{
Rethinking IR from the Amazon
}

DOI: http://dx.doi.org/10.1590/0034-7329201600203

Rev. Bras. Polít. Int., 59(2): e003, 2016

\section{Abstract}

This article proposes Amazonia as a site to think world politics. The Amazon is invisible in the study International Relations (IR), yet its experiences are deeply global. I present the international dynamics at play in Amazonia at different historical moments to posit that this periphery has contributed to forging the political-economy of what is refer to as the core. The Amazon's absence from the study of IR speaks about the larger inequality in processes of knowledge production. Serious engagements with Amazonia are one way to invite a plurality of worlds in the production of theories, disrupting global divisions of labor in knowledge production ally.

Keywords: International relations; Amazonia; core-periphery relations; Global South; knowledge production.

Received: November 5, 2015

Accepted: April 19, 2016

\section{Introduction}

$\mathrm{n}$ popular discourse, as well as in the discipline of
International Relations (IR), the Amazon is not exactly the first place one looks for global politics. It exists, in popular imagination, as a land without history, wild and remote. In this depiction of the Amazon, there are pristine rainforests inhabited by isolated tribes in need of preservation from global forces. Many accounts lead readers to imagine adventurers

Copyright:

- This is an open-access article distributed under the terms of a Creative Commons Attribution License, which permits unrestricted use, distribution, and reproduction in any medium, provided that the original author and source are credited.

- Este é um artigo publicado em acesso aberto e distribuído sob os termos da Licença de Atribuição Creative Commons, que permite uso irrestrito, distribuição e reprodução em qualquer meio, desde que o autor e a fonte originais sejam creditados. navigating legendary uncharted waters in search of uncontacted peoples, failing to realize that the Amazon rivers were subject to systematic human manipulation, and that it is Brazil's most rapidly urbanizing region. It is portrayed as a pure source of nature capable of containing global warming, rarely recalling that the Amazon rubber enabled the automobile revolution, which fueled today's climate crisis in the first place. There is a profound gap between what is (un)told about the Amazon and the international interactions at play on the ground. 
The Amazon is commonly appraised at the margins of world politics as some apolitical Eden that resists external forces of modernization (Slater 2002). The Amazon is not perceived as a place to study IR because it is imagined outside the modern state. When conceptualized, it tends to be as a uniform, unified entity, a frontier of civilization. The absence of the Amazon in what constitutes legitimate world politics seems to be the result of who defines political theory, from where, and for what purpose (Cox 1986), rather than serious historical considerations. The Eurocentric gaze has continuously identified Amazonia as its quintessential other, starting with its naming. The word Amazon refers to a mythical people of female warriors living outside Greek civilization, who subverted Greek rules (especially with regards to men and marriage) ${ }^{1}$. They embody an untamed, barbaric otherness to be conquered, and a foil for cultured (European) society. Much of the West still imagines Amazonia as 'wild' despite abundant geo-archeological evidence that it is a garden which forests and rivers have been efficiently managed for millennia (Raffles 2002; Mann 2005) ${ }^{2}$. Popular and scholarly portrayals of the region focus on its ecological exuberance rather than its dynamic political history (Hecht 2013). When politics reach the Amazon, it tends to be from ecological perspectives which emphasize how external powers use (and abuse) its natural resources.

The paradox is that Amazon experiences are in fact deeply interconnected with global dynamics. Moreover, although the name confers a singular entity, it is in fact a multinational region that contains many variations, a place of multiple histories. The modern world has long been influencing Amazonia, and Amazonia has in turn contributed much to forging what we now refer to as the global North ${ }^{3}$. Scholars such as Susanna Hecht (2013) have sought to debunk Amazon otherness providing close-up analyses of forestry management and insurgent politics, depicting an Amazonia more ordinary than foreign, irremediably international. Overall, however, social sciences such as anthropology have otherized Amazonia. The discipline of IR, in contrast, made it invisible. Depending on where one stands, it is easy to ignore a lot of the world. IR's omission of the Amazon is similar to the absence of centuries of slave trade.

The region has been dismissed as irrelevant to world politics in the same way that the Haitian Revolution was not recognized as a critical juncture in the international history of state-making (Buck-Morss 2009). This invisibility speaks of a larger challenge of locating the non-core in scientific theory. The Amazon is not at the center, but it is constitutive of the center. Mainstream IR theory on stateness has left out experiences of peoples living in the periphery. Although Amazonia is diverse, complex, and heterogeneous, IR's discursive representation leaves it invisible at the margins of global politics. This essay claims Amazonia as its object of study

1 The river was first named Nueva Andalucia, then Frey Gaspar de Carvajal's chronicles of women warriors along the river quickly led to the name of Amazons, from the Greek a-mazon (without-breast).

2 Researchers found a set of "garden cities" built in the forests of the south-central Amazon as early as 1250 (Mann 2005).

3 I interchangeably use global North/ West/ core to refer to the same locale of dominance and global South/ non-West/ periphery to refer to places of subalternity. 
to unpack IR's disciplinary logic, a logic which is also present in other areas of social sciences, especially political science.

My attempt to revisit IR from the Amazon perspectives is inspired by a critical literature which challenges IR's state-centrism and questions the discipline's fixation on Westphalia sovereignty, positivist inquiry, and entrenched imperialism (Hobson 2012; Jackson 2011). Critics have used gender and race perspectives to expand conceptualizations of the international (Tickner 2011; Henderson 2013) while wrestling with the core-periphery divide that obscures the social construction of knowledge (Tickner and Blaney 2013). My attempt to revisit IR from an Amazon perspective is inspired by these calls to pluralize IR beyond disciplinary borders. I propose a serious engagement with the Amazon to disrupt established thinking about world politics and towards fruitful theoretical spaces in IR. In particular, I contest IR's modernity/ tradition binary as well as the nature/culture boundary that dismiss "natural" places like Amazonia to the political periphery. This neglect makes it extremely difficult to understand or study noncore thoughts on international affairs. Searching for Amazon perspectives on world politics, even with regards to issues that directly affect it such as environmental change, makes one feel like Virginia Woolf looking for women in British literature.

The analysis will proceed in three steps. The first section identifies international dynamics at play in the Amazon through different historical moments to show how the periphery is and has always been entangled with the global core. In doing so, it posits Amazonia as a transnational space deeply interconnected with the making of modern states. A second section then examines the absence of the Amazon in the study of IR. Critical insights on core-periphery dynamics explore why the global South remains so marginalized in processes of knowledge production. The last section builds on the historical analysis to suggest that Amazonia is a fertile location for conceptualizing IR, not by providing a road map but rather by emphasizing the theoretical potential of Amazonia for critical scholarship.

\section{Worldly Amazons}

The Amazon is an ecological system that covers about 40 percent of South America. It encompasses the largest water reserve and the largest rainforest in the world, boasting unrivaled biodiversity. It is also, like Europe, a historically complex and socially porous region with geopolitical borders hard to define. The Amazon River basin is shared among Brazil (63\%), Peru (10\%), Colombia (7\%), Bolivia (6\%), Venezuela (6\%), Guyana (3\%), Suriname (2\%), and Ecuador (1.5\%) (Garcia 2012). Amazon borders are therefore porous, and it is often unclear where the Amazon starts or when it ends. People tend to identify themselves as Amazonians or of their ethnic group rather than their country of nationality. As a result, Amazonia is not a single referent, but it is strikingly diverse whether ecologically, politically, or ethnically. Historically 
complex and socially rebellious, Amazonia has persistently resisted the homogenizing presence of states, while being influential in the political economy of state formation.

Amazon societies have a complex history that predates their encounter with Europe. Terra preta, a man-made dark soil mixed with Indigenous ${ }^{4}$ artifacts to increase fertility, reveals anthropogenic forests throughout the Amazon (Mann 2005). As more terra preta is uncovered, partly due to deforestation, growing geo-archeological evidence demonstrates the existence of dense, fully sedentary populations across ecological settings from Colombia to Brazil (Rostain 2013). Settlements in pre-contact Amazonia suggest that people have been modifying their landscape for centuries (Whitehead 2003). What appeared as wilderness to Europeans was elaborated forestry that provided food, medicine, and tools to large societies. As many as one million people walked the causeways of the Beni, eastern Bolivia, leaving waste mounds larger than Pompeii. Archeologists also found millennia-old ceramics in the lowlands, a two thousand year old 'Amazonian Stonehenge' in the Caribbean Amazon, and the ruins of a three thousands years old house in the Andean foothills. At the time of the European arrival, Amazonia was home to developed societies that used astronomical observatories (Hecht 2013). If Europeans who first ventured down the Amazon River described large settlements, it is because the region was indeed well populated.

The Amazon is a transnational space deeply interconnected with the making of modern states. Already in the late sixteenth-century European empires were forging their political, legal and economic authority on Amazon territory. The Spanish first connected the Andean highlands to the Atlantic when Francisco de Orellana traveled down the Amazon River in 1541. European explorations flourished on the valuable tobacco trade, and the prospect of the Amazon River as a profitable (and safe) overland route to traffic Inca silver and gold across the Atlantic. Within a century, the Amazon River had become a focal point of European trade and settlements. English, Irish, Dutch, Spanish, and Portuguese traders and settlers were erecting fortifications on the rivers to bolster rival claims to sovereignty (Benton 2009). In the seventeenth century, the Portuguese were busy destroying Dutch forts from the Xingú to Belém, including the monopoly of the West India Company in a region that the Dutch already called New Holland ${ }^{5}$. British colonies flourished into the mid-seventeenth century, with hundreds of settlers on plantations scattered along 300 miles of Amazon rivers. They charted Amazon rivers as early as 1595 and as far as Xingú. By 1619, they had established the Amazon Company under Capt. Roger North (Wroughton 2006). These maritime enterprises on Amazonian rivers helped forge the British commercial empire. Sir Thomas Roe, in fact, created settlements on the Oyapok River in Amazonia to later become ambassador to India (Beer 1908). The Dutch West India Company and the British Amazon Company are testimony to the imperial competition at play through trade in the region.

\footnotetext{
4 "Indigenous" is capitalized because the Chicago Manual of Style $(8.41,15$ th edition) indicates that names of ethnic and national groups are to be capitalized, including adjectives associated with these names.

5 In 1654, Recife's Dutch colony fell to the Portuguese. Many of the nearly five thousand people returned to the Netherlands, some scattered in the Caribbean, and others migrated north to settle in New Amsterdam, i.e. Manhattan. The Dutch later ceded Manhattan to the British in exchange for Suriname.
} 
Amazonia became a center of territorial claims. Susanna Hecht (2013) has retraced the scramble for the Amazon because, in spite of its apparent remoteness, the Amazon is a highly cosmopolitan place at the heart of state-making. The Caribbean Amazon, which Europeans referred to as the Wild Coast, was at the intersection of a tropical 'great game' between France, England, the Netherlands, Spain, Portugal, native Amazonians, and maroon communities called quilombos. After battles for strategic trade and territorial claims on this immense terra nullius, Europeans developed legal (and extra-legal) mechanisms in an attempt to control native labor. The Amazon rivers were difficult routes to transport gold from the Andes, so European powers used it for slave trade instead, kidnapping and enslaving native populations ${ }^{6}$. By the midseventeenth century, Spain, Portugal, and the Catholic Church were negotiating international trade agreements to regulate the enslavement and trafficking of native populations on the Amazon River. Jesuit missionaries oversaw the Indians and controlled most trade until the Portuguese Crown decided to lay claim to the economic bonanza and expelled them in 1759 . The native slave economy in the Lower Amazon fueled international trade through the eighteenth century (Alencastro 2006).

The region was entangled with Europe both commercially and politically. Amazon ports were closer and more accessible to Portugal than ports in Salvador and Rio de Janeiro, and in some ways more interconnected with the Atlantic trade flow. What is today claimed as Brazilian Amazonia was an autonomous region called Grão-Pará and Maranhão until 1772; the region was directly administered by Lisbon since 1621. Even after that, the Grão-Pará remained politically, legally and economically independent for another century. In practice, Amazonia was fully integrated to Brazil in 1855, most of the region (since Brazil's share is over 60\%) functioned largely as an independent country until the rubber era.

It is perhaps because the region was so economically dynamic and politically autonomous that is was also rebellious. One example is the social revolt that raged through the lower Amazon from 1835 to 1840 in what is today the state of Pará. The Cabanagem rebellion revealed the strength of insurgent citizenship in the lower Amazon (Harris 2010). African diasporas and Indigenous communities led the Cabanagem ${ }^{7}$ to defend autonomous lifestyles. Like other powerful rebellion of its century, such as Bahia's Sabinada (1835) or the Canudos war (1897), the Cabanagem contested political exclusion, land grabbing, and forced labor as much as centralized forms of authority. It opposed domination by the Portuguese monarchy as well as internal forms of colonialism under Brazil's newly formed empire ${ }^{8}$. The rebellion successfully

\footnotetext{
6 Alencastro (2006) estimates the number Indigenous peoples enslaved between 1625 and 1650 in Brazil equals that of African populations brought to Brazil by Dutch and Portuguese ships in the same period.

7 The word Cabanagem refers to the people who lived in cabanas, the region's poorest housing. The use of cabanos to refer to residents of the huts made of palm leaves and wood carries negative connotations of backwardness and poverty, and was retrospectively applied to the participants of the rebellion (who describe themselves as defenders of the homeland and freedom). See Harris 2010.

8 Brazil was a Portuguese colony until it became the home of the Portuguese colonial empire in 1808, when the King fled Napoleon's invasion of Lisbon and settled his court in Rio de Janeiro. In 1822, Brazil declared Independence from Portugal and became an Empire until a military coup d'Etat established the New Republic in 1889.
} 
resisted the central government for years before being violently repressed ${ }^{9}$. Amazonia was already the stage of political insurgencies in the nineteenth century.

It was the rubber boom that catapulted the Amazon most forcefully to the global forefront. International demand for rubber took off at a time when the Amazon was the world's sole supplier (Weinstein 1983) ${ }^{10}$. Goodyear's discovery of vulcanization in 1839 sparked the bicycle and automobile industries, interconnecting further the European and US economies with the Amazon. As demand increased, the rubber that used to be collected by Indians was soon handled by rubber-barons who brutally enslaved local populations. By the time Hevea seeds were successfully transferred to Asia in the early twentieth century, triggering the collapse of Amazonia's rubber monopoly, a violent genocide had decimated the Indigenous population and pushed survivors to nomadic lifestyles (Rivera 1924), ${ }^{11}$ Manaus had an Opera House, and Henry Ford had tried and failed to build an industrial town on a plot of rainforest twice the size of Delaware (Grandin 2009).

Although the internationalization of the Amazon during the rubber boom is relatively well known, its role in supporting the Allies during World War II is less so. The Amazon became a strategic provider of rubber for the Allies in 1942 after Japan's occupation of Southeast Asia cut off more than 90\% of the global rubber supply (Wilkinson 2009). The Roosevelt administration called for a push in rubber tapping across Amazonian rainforests, and Brazil's President Getúlio Vargas responded with a "Battle for Rubber" that shipped nearly 30,000 'rubber soldiers' from the arid northeast to rubber estates in the Amazon. The modest increase in rubber production may not have been of much significance in the final outcome of World War II. Yet this enterprise meant that North American technical advisers, Brazilian government agencies, the Roosevelt Administration, migrant rubber tappers, rubber elites, and Indigenous groups, all interacted in a wartime enterprise to supply European needs in wartime. It was not the first nor the last time that global, national, and regional actors converged in the Amazon to influence world politics.

Vargas' rubber initiative is one of several monumental projects in Amazonia. The MadeiraMamoré railroad was planned in the late nineteenth-century and construction started in 1907. The project, one of the first large US engineering project abroad, brought over 20 thousand workers from more than 50 nationalities to build 366 kilometers of railroad at the western borders of the Brazilian Amazon. Half a century later, Brazil's military junta inaugurated the Trans-Amazonian Highway, a four thousand kilometer road, facilitating communication to remote areas (which a new generation of 'adventurers' now 'explores' on bicycles). The Amazon has also seen the development of energy projects. In Brazil, the Balbina hydroelectric plant inundated 240 thousand hectares in 1989; and the current Belo Monte project is the largest

9 The five years of civil war killed about half the population of Grão-Pará.

10 The origins of the plantations producing $98 \%$ of the world's natural rubber is traced to the domestication of a single Amazonian species, Hevea brasilensis. See Schultes. 'The Domestication of the Rubber Tree,' Economic and Sociological Implications 52(4)(1993): $479-485$.

11 The extreme violence at the infamous Casa Arana, on the Putumayo River, Colombia, led to an international tribunal. 
of 60 hydroelectric plants planned for the Amazon. The Peruvian and Ecuadoran Amazons have been overrun by extractive oil industries since the 1970, with China replacing the US in expanding the extractive frontier today.

This history of international interactions explains complex migration flows that inevitably diversified the population. Amazonia was the home to many runaway slave communities. Almost four times as many Africans as Europeans came to the Americas, and tens of thousands of them fled inland to Indigenous territory to escape slave labor (Hecht and Mann 2012). Africans were a majority population together with the Indians, forming quilombos deep into Amazonia. The more European entrepreneurs, religious orders, and migrant workers settled in, the more Amazon populations diversified. Photographs of the Madeira-Mamoré railroad show Hindus and Ottoman Turks posing in traditional attire against a rainforest background circa 1910. In the 1930s, Japanese emigration focused on jute agriculture (Brasil de Sá 2010). Today, Haitian immigrants flood across Brazilian borders to enter a booming construction economy. In parallel to migration inflows, many natives were killed by disease or enslaved, while others forcibly displaced or escaped up tributaries. The Coordinator of Indigenous Organizations of the Amazon Basin (COICA) estimates that Indigenous peoples constitute less than 10 percent (2.7 million) of the Amazon's population today.

To put it simply, Amazonians are incredibly more diverse than the authentic naked peoples portrayed in black and white photo-reportages in Vogue magazine today. In the twenty-first century, Indigenous peoples who live on 'intangible' ${ }^{12}$ territories are on Facebook, successfully mobilizing information technology to defend their land from intrusive development projects such as oil exploitation and hydroelectric plants. Manaus was once the place where cosmopolitan elites built an opera house to imitate Parisian lifestyle in the rainforest. Now it is an operating base for the international drug trade. The Amazon remains at the center of a global, albeit illegal, economy as one of the world's busiest routes for drug trafficking, supplying most of the cocaine on global markets. The Western world has long been influencing the Amazon, and the Amazon has in turn contributed much to forging what we now refer to as the global North.

None of this political history would be exceptional if it were not located in a place perceived to be detached from world history. Perhaps it is clear by now that there is nothing isolated or untouched about the Amazon. To the contrary, Amazonia's international relations merit attention because they are extremely complex and far-reaching. They continue to flourish today. It would take a book rather than an essay to provide a fair overview of Amazonia's current international interactions. Given this history, it is surprising that the Amazon has not been explored more closely as a nexus of world politics by scholars of international relations.

12 Intangible zones are large areas of forest declared off-limits to development projects that are reserved for Amazon Indigenous peoples. 


\section{Invisible margins}

Scholars seem to consider the Amazon irrelevant to the study of world politics. A survey of the International Studies Association (ISA) reveals that the Amazon is virtually absent from the discipline. Since 1959, the ISA has gathered over six thousand members and managed to get a consultative status with the United Nations. The organization publishes six peer-reviewed journals that are highly praised in the field: International Studies Quarterly (ranked the second most influential IR journal in 2012), International Studies Review, International Studies Perspectives, Foreign Policy Analysis, International Political Sociology, and International Interactions. According to the records available online, none of the journals has ever published any article related to the Amazon. The only exception is a short book review published by the International Studies Review where one of the books under review was about deforestation in the Amazon.

The Amazon is also invisible at conferences. A review of the nearly 300 pages of ISA conference programs involving nearly one thousand participants reveals that it is virtually absent from research agendas. In 2009, there was nothing about the Amazon. The 2010, 2011, and 2012 conferences each had three individual paper presentations addressing the Amazon; the 2013 conference only two. The Amazon does not figure in ISA publications or conferences because it is not part of the conceptual map of the discipline whose central avowed concern is to understand the world. It is not invoked to explain international relations, political economy, or security paradigms. A study of citations or university courses would most likely confirm the Amazon's invisibility in the study of international relations. This absence speaks volumes. It implies that the Amazon, like other 'marginal' locations, is not considered a site where world politics take place, nor does it influence global economics or determine foreign policy.

The Amazon is invisible both because it is considered a place of nature, and is a territory in the global South. This invisibility indicates the (non)place of the periphery in the making of IR. Isolated critiques of US dominance in IR have recently evolved into more substantial efforts. Routledge publishing, for instance, dedicates the series Worlding Beyond the West to analyze how core-periphery dynamics influence knowledge production. Arlene Tickner (2013) has been particularly critical of IR's center-periphery configuration, which she says favors analytical categories and research programs that are defined by academic communities within the North while also reinforcing Northern dominance within international practice. Yet the discipline remains starkly US-centric. A survey shows that US authors account for $58 \%$ of the assigned readings in undergraduate IR classes throughout the world-and over $70 \%$ of readings in undergraduate classes in the US (Maliniak et al. 2012). The assigned topics further highlight patterns of dominance. Realism is the most widely taught paradigm in IR (feminism only accounts for $7 \%$ ), almost $60 \%$ of scholars describe their work as positivist; international security is by far the main area of research. Only $5 \%$ of $\mathrm{PhD}$ course material is assigned to study regions, mostly Europe. 
The construction of IR knowledge is concentrated in one place. All of IR's 20 most influential authors are from the English-speaking global North. Most IR scholars conduct primary research in non-native languages, except for English speakers, who tend to speak only their mother tongue. The top three-ranked IR journals are in the US (International Organization, International Studies Quarterly, International Security), and US-based authors account for 80\% to $100 \%$ of articles published in any given year between 1970 and 2005 (Friedrichs and Wæver in Tickner and Wæver 2009). Authors based in Europe represent, on average, less than 10\% in the top four IR journals, including the British-based Review of International Studies. The 'rest of the world' is essentially invisible. What is worrisome is that US dominance is growing as more scholars need to publish in 'internationally recognized' venues to secure job stability.

The invisibility of Amazonia, and the concomitant non-place of the periphery in IR, is symptomatic of a bigger problem across the social sciences. The analysis of participation in peerreviewed journals and of citation patterns exposes the entrenched inequality that characterizes academic knowledge production beyond IR (Tickner 2013, 632). Almost 60\% of the total literature covered by the Social Sciences citation index is authored or co-authored by scholars affiliated with the United States; all of western Europe accounts for 25\%, Latin America 1\% and the entire African continent for less than 1\% (Keim 2008 in Tickner 2013). The construction of knowledge in the social sciences is by and large a business of the global North, in academicrefereed journals edited in English. These power dynamics shape intellectual dependency, most scholars having to adjust their work to agendas and methodologies defined at (by, and usually for) the core.

One reason for the Amazon's absence from IR is the lack of scholars from the area who could enrich scholarly debates with their own perspectives. There are limits for doing what is commonly identified as theory in the periphery. Foundational thinkers have emerged from the periphery, forging a forceful scholarship about developmental economics in Latin American and post-colonial studies in India. The Brazilian Eduardo Viveiros de Castro, whose concept of Amerindian perspectivism influenced western thought, is one of the exceptions that proves the rule. The problem is not that there is no science in the periphery; it is that science here in the periphery tends to look different. The challenge is that its praxis is too different to generate interest in the core. Research produced by or in the South is often dismissed as case studies, not theory, and alternative forms of knowing the world tend to be marginalized as not constituting 'real IR' (Tickner and Blaney 2012). The core-periphery inequality in academic production creates a conceptual and epistemological straitjacket that limits what counts as valid scientific knowledge. These asymmetries restrict IR epistemology in the global South, where local scholars end up perpetuating their own marginalization. They reproduce hegemonic knowledge by engaging mostly theory produced at the core. The fact that most of our knowledge about international relations is produced in and by the global North about itself excludes not only other forms of doing IR, but also the voices of most of the world. Today's intellectual division of labor is anchored in the global imperial order. The Eurocentric core is the primary site of 
scientific production, especially theory building. Peripheries, in turn, offer case-studies without universal reach. IR scholars are aware that journals reproduce the views, theories, and research methods that circulate in the North, giving little chance for other ways of seeing to emerge. Critical scholarship accuses IR theory of defending western civilization (Hobson 2012) and selfvalidating positivist perspectives against other methodologies (Jackson 2011). Like English, the canonized language of IR ensures entry barriers to keep "outsiders" at bay. At least in this field, the rest of the world seems doomed to catch up with the ideas of the North, forced to invoke its science, relate to its epistemologies and follow its methodologies if it wants to be validated.

IR theorizing takes place in the US. Expanding theory-making to places like Amazonia may be a more challenging enterprise than expected. It is a practice that may not be easily transposable (that would assume a universalism of ways of making sense of the world). Scholars have stressed the significance of place for theory. Edward Said's (1983) 'traveling theory' contextualized theory to its site of production. Yet Tickner's research implies that it may not be possible to democratize the production of knowledge by simply taking theory elsewhere. First, grand theory does not travel well, partly because it often fails to explain places like Amazonia. Second, places like Amazonia end up disengaged from theory. If one challenge is that theory made in the global North is often not all that useful to understand the global South, another one is that the global South is more concerned with practice than theory. Theory is not perceived as useful to solve 'real' issues in the periphery, which is marked by a fluid interaction between academe and government (Tickner 2008). In a periphery where borders between theory and praxis are porous, scholars are often involved in praxis in ways rarely experienced by their counterparts at the core.

My critique of IR echoes a larger concern about the need to validate the forms of intellectuality as practiced in the non-core. Raúl Prebisch spent a life concerned with addressing tensions between centers and the periphery. In 1948 he pushed for the creation of an Economic Commission for Latin America and the Caribbean (CEPAL) within the United Nations in Santiago, Chile, with the overt purpose of creating a space to enable Latin American thought on development (Dosman 2008). In the 1970s, Latin America was the sole place across the global South to develop economic theories to respond to its contextual realities, with no equivalent in regions like Asia or Africa. Later, Albert Hirschman fought modernization theorists as he insisted on the importance of the periphery generating its own theory (Adelman 2012). Both Prebisch and Hirschman believed in the significance of producing knowledge in and for the periphery, from the ground up.

The challenge is not to take theory to a 'new time and place,' moving it from Paris to Budapest, or to Manaus for that matter. Rather, the question is whether the non-core will bother with appropriating theory as a tool to express its own perspective, or whether it is an exercise characteristic of autistic universalist efforts at the core. The solution to democratize the production of knowledge may not be to export the methodology of the core to the periphery, 'enabling' Latin America and Africa to do (Eurocentric) theory. It is necessary to validate the praxis and knowledge of the periphery in its own terms, even if they appear as non-positivist 
practices that look nothing like theory to the eyes of the North. It implies recognizing other forms of knowing, whether it is engaging reflexivity (Tickner 2013), understanding how personal narratives influence IR's theoretical articulations (Inayatullah 2011), or validating Indigenous ways of knowing (Beier 2009). It also implies legitimizing case-study perspectives as opposed to mainstream forms of Grand Theory. It implies, among other things, doing IR from the Amazon.

Michel-Rolph Trouillot (2003) called on anthropology to dissolve its own theoretical premises for the field to remain viable. He invited anthropologists to break with the savage/ civilized dichotomy to produce a cultural critique able to historicize their field. IR too needs to radically rethink its own internal tropes if it is to remain viable. This requires a historicization of the state to move beyond the core-periphery impasse, a reflexive IR committed to Ann Tickner's (2011) calls to reappraise its own foundational stories. The plurality of experiences between the 'West' and the 'Rest' marks a structural problem of difference in IR (Blaney and Inayatullah 2011). The core-periphery divide is so vast and so complex that post-colonial scholars like Robin Shilliam have publicly proposed killing IR as a way out of the impasse. Perhaps non-core perspectives are simply incommensurable with those of the global North. Yet having acknowledged our differences, our best shot is to try to subvert them.

\section{World politics from Amazonia?}

How can Amazonia influence IR theory given that the region's history is tightly embedded in international dynamics of state making? This essay posits the Amazon as an insightful periphery to rethink world politics in the plural. Thinking the core-periphery debate through notions such as temporality permits us to recognize how the Amazon is intrinsically related to the temporality of the modern state. I emphasize the significance of Amazonia in world politics not only to acknowledge the international dynamics at play in the region, but further to enable a more comprehensive way of seeing IR. My goal is to engage the theoretical potential from Amazon peripheries rather to list how "to do" IR from the Amazon. In this section, I suggest insights as to why Amazon perspectives may provide different ways of knowing world politics in general and alternative venues to tackle environmental change in particular.

The first good reason to think world politics from the Amazon is to pluralize IR. An Amazonian IR is fundamentally other. Bringing the periphery into the core will permit us to decolonize the discipline. It will bring untold stories into IR, and inevitably retell its conceptual foundations. It will complement new perspectives and histories to understandings of what constitutes IR, renew research agendas, expand global praxis. Conceptualizing colonial battles along Amazonian rivers, for instance, will permit us to historicize (and delocalize) the formation of European claims to sovereignty. Similarly, recognizing Indigenous struggles for territoriality in international courts permits IR to reimagine sovereignty as plural construct. Peripheral visions can contribute alternative knowledge to break disciplinary straitjackets. Truly decolonizing IR 
means recognizing the non-core capacity to generate theory. Yet it also means destabilizing theory as we know it.

It is not sufficient to add Amazon diversity to the study of IR. Efforts to decolonize IR will require that the discipline expands its knowledge base and turns it upside down. More than tolerating contributions from Amazonia, IR will decolonize only when it is able to disarm hegemonic epistemologies. It is important to think IR theory from the Amazon because it is an attempt to contest the divide between the universal grand theory and the localized case-study.

Thus, IR from Amazonia shows how the global North and South are not only related, but also indissociable. The core does not exist without the periphery, and the idea of a wild Amazon only acquires meaning as a category relational to the civilized West. Anthropologists Jean and John Comaroff (2012) insist on theory from the South not only because African modernity has always had its own trajectories, but especially because North and South are relational categories. State modernity, they claim, is the result of a "world-historical production" (Comaroffs 2012, 6). Modernity separated worlds that are in fact intimately articulated. In many ways, the Europe we know today emerges out of its colonial encounters, with peripheries like the Amazon being co-constitutive of state modernity. This is what Frantz Fanon meant when he wrote "Europe is literally the creation of the Third World"13.

Subaltern studies were core to Eurocentric projects, even if they were not allowed to speak. Other peoples and places have been the looking glass through which the core defined itself. The global North was constructed adopting techniques and knowledges that pre-existed in the Amazon, Africa and elsewhere. Without Amazon rubber there would have been no Fordism or polluting cars in the first place. "Empty", "uncivilized" spaces were key to European material life (rubber) and self-consciousness (Indigeneity). Uncivilized Amazonia, like Indigeneities, is part of European representations of difference. The problem with the epistemological basis of IR is that the state is its narrow object of study.

Theory-making in IR results in obscuring the amazons of the world. The discipline has no option but to move beyond the core-periphery dynamic if it is to see better the world we actually live in.

Obfuscated knowledge impairs politics. When the Spaniards arrived in the Andes, they had their own expectations of what sacred idols should look like-man-made, anthropomorphic idols. They could not see 'art' that was aesthetically pleasing, and concluded that Andean idols were "ugly" (Dean 2010,11). Spaniards were unable to apprehend rocks as Inca culture saw them (animate, transmutable, powerful and sentient), thus failing to access the broad array of beliefs and relationships people forged with them. Their inability to access meaning in Inca rock echoes a larger European inability to read the New World. Today, IR is similarly impaired; it cannot accurately understand political configurations that differ from those it has defined for itself. Just as the Spaniards failed to see authority in Inca rock, the failure to see the global 
significance of the Amazon signals an impaired understanding of the world IR is supposed to explain. A world politics of the Amazon calls for a recognition of the global South as a site of political influence as much as it challenges the canons that structure IR knowledge.

State-centrism relegates places in the non-core to the past by enforcing the Eurocentric civilization line. Western thinkers tend to locate non-western peoples in the European past (Helliwell and Hindess 2011). "In the beginning, all the world was America," claimed John Locke, in his Second Treatise of Government, back in 1690. This Western practice of temporalizing difference still permeates knowledge production today. It infuses economic discourse about 'emerging' economies and 'developing' societies, which evidently upset scholars like Prebisch and Hirschman. The non-core at large is located in subaltern temporalities outside the modern temporality of the (European) state. A fundamental trait of colonial projects is to bring the 'uncivilized' into present time. British rule over India was tight to British time because to civilize meant, among others things, to bring others into European time (Ogle 2015). This temporal dimension created false dichotomies between past and present, giving birth to a defective political thought stuck in the 'first in Europe, then elsewhere' (Chakrabarty 2000).

Temporality is a key myth of modern state-making. The European dominion of the time of the state created subaltern temporalities, dislocating non-western spaces to a-temporal dimensions. Peoples outside the temporality of the state became peoples without history (Wolf 1982). The Amazon, the Arctic, the Himalayas, the Sahara are theorized as places of nature in contrast to stateness, and as such are relegated to a-temporal places beyond history-making. They are still perceived as Locke once saw America, 'before politics'. Paccha, a Kichwa word describing both time and space, collapses the "here" into the "now", making time and space two aspects of one single concept. Kichwa, the most spoken Indigenous language in the Americas, situates time. Eurocentrism too tends to situate people's space in time, especially 'other' people in past times. The hegemonic temporality of the state defines present time, leaving that which is "apolitical" outside the paccha (time/place) of the modern state.

This political articulation between time and space enabled the doctrine of discovery. European monarchies and the Catholic Church invoked the concept of terra nullius to grab lands 'without a past'. In 1550, the Valladolid Debate between Bartolomé de las Casas and Sepulveda argued about whether Indigenous peoples had political autonomy, and therefore history. Then as now, Indigenous peoples have to prove their political existence to claim authority over their land. This is clear in current Australian and US law, which require that natives prove their history through state documentation in order to acquire authority over their ancestral land. Indigenous peoples have to make their own history commensurable to the temporality of the state to exist politically. In other words, recognition of political history brings recognition of political territory. Time and space are central elements for critical inquiries seeking to restore the peoples (and places) without history. This is why the Amazon is a strategic place to rethink stateness, sovereignty, and territoriality. 
The Amazon is an insightful periphery to think IR in various ways. In addition to bringing new blood into critical currents, Amazon historical experiences can free IR from further inbreeding. An 'Amazonian IR' answers calls on what IR looks like when practiced in the non-core. It offers an unusual periphery to expand the horizons of non-core thinking while contesting the disciplinary imperialism of state-centrism. Furthermore, the Amazon is a place where epistemological breakthroughs are possible when trying to rethink stateness. The idea of an Amazonian IR proposes to anchor theory-making in area studies, blurring a long-standing disciplinary divide. It responds to scholarly calls to think ourselves beyond the nation and to look within it (Chatterjee 2010) and to reach beyond the inadequacies of the European nation-state. Alternative histories open up our imagination. Following critical scholarship which established the limits of seeing through the lens of the state (Scott 1998), we can explore the Amazon as an example of political modernity beyond the state.

Theoretically, Amazon territoriality disturbs IR. The Amazon lies outside the boundaries of IR, yet it is constitutive of IR because the region is central to world politics historically, as well as in its theoretical and political construction. No government adequately represents it internationally, yet it is embedded in global flows, financial and atmospheric alike. The global is deeply imbricated in the multiple territorialities of the Amazon. It is a co-producer and a solution of the global climate crisis. It was the Amazon rubber that enabled the car revolution in the North, and the Amazon crude oil that now fuels the climate crisis. The Amazon is also at the heart of the solutions to tackle planetary crises, not only because it represents the lungs of the planet and a depository of biodiversity for future generations, but also for the environmental practices it has successfully maintained. Amazon territoriality does not fit within IR disciplinary categories, and for this reason it guides us towards alternative forms of seeing IR.

Rethinking IR from the Amazon, offers us an opportunity to employ specific modes of inquiry to contribute to global understandings (ethnography in the world system to ethnography of the world system, Zimmermann 2013). More than bringing IR to the Amazon, it implies using the Amazon as an analytical category in the construction of theory. Such approach also allows us to move beyond the immediacy of our different experiences in the core and the non-core (Scott in Zimmerman 2013,337), and to escape the trap of thinking in terms of incommensurable experiences.

Furthermore, an Amazon-based approach to world politics could broaden debates about climate change. There are some problems in the way the global North conceptualizes nature. Take, for instance, two scenarios of North American environmentalism and recent debates on the anthropocene. One concentrated on the conservation of 'wild' landscapes, protecting Indigenous Amazonians for being part of wild rainforests. The others posits Amazonians as part of the human species that is generating irreversible climate change. In both cases, Amazonians are portrayed as lacking agency in a sort of conceptual absolutism. Neither perspective acknowledges the complexity of their agency. Perhaps integrating international perspectives from Amazonia (and the Sahara and the Arctic) is one way to expand existing ways of seeing the climate change debate. 
Perceptions of a wild Amazon betray the divide between politics and nature and the difficulty the West/global North has in conceptualizing a post-enlightenment relationship between men and nature. An Amazonian IR defies the enduring antithesis between state and nature. Bringing the Amazon into IR will not only shed light on invisible histories and emancipate IR scholarship. It can also inspire new ways to bridge the North-South divide on environmental policy.

\section{Conclusion}

The Amazon is a resourceful space from which to think world politics. In Songlines, Bruce Chatwin tells of invisible pathways across Australia that Aboriginals sing into existence. This essay is an invitation to write the international relations of the Amazon into existence. First, Amazonia is all too international to remain invisible in the study of world politics. Although the Amazon landscape has been politicized for millennia, it remains pretty much untouched by IR. Second, the proposal to rethink IR from Amazonia responds to an epistemological impasse in the discipline. IR is unable to see the Amazon because the non-core is dismissed as irrelevant to scientific theory. The Amazon is a strategic site to debunk the core-periphery dichotomy in IR by emphasizing their embeddedness. The call to do an Amazon IR is an effort to rescue the Amazon from historical oblivion as much as one to free IR from hegemonic processes of knowledge production.

\section{Bibliographic references}

Adelman, Jonathan. Worldly Philosopher: The Odyssey of Albert O Hirschman. Princeton: Princeton University Press, 2012.

Alencastro, Luis F. “Le versant brésilien de l'Atlantique-Sud: 1550-1850”. Annales 61(2)(2006): 339-382.

Beier, J. Marshall. International Relations in Uncommon Places: Indigeneity, Cosmology, and the Limits of International Theory. New York: Palgrave, 2009.

Benton, Lauren. A Search for Sovereignty: Law and Geography in European Empires, 1400-1900. Cambridge: Cambridge University Press, 2009.

Blaney, David and Naeem Inayatullah. The Problem of Difference in IR. New York: Routledge, 2011. Brasil de Sá, Michele E. A Imigração Japonesa no Amazonas a Luz da Teoria das Relaçóes Internacionais. Manaus: FAPEAM, 2010.

Buck-Morss, Susan. Hegel, Haiti, and Universal History. Pittsburgh: Pittsburgh University Press, 2009. Chakrabarty, Dipesh. Provincializing Europe: Postcolonial Thought and Historical Difference. Princeton: Princeton University Press, 2000.

Chatterjee, Partha. Empire and Nation: Selected Essays. New York: Columbia University Press, 2010. 
Comaroff Jean and John Lionel Comaroff. Theory from the South: Or How Euro-America is Evolving Towards Africa. Boulder: Paradigm Publishers, 2012.

Cox, Robert W. "Social forces, States, and World Orders: Beyond International Relations Theory." In Neorealism and Its Critics, edited by Robert Keohane. New York: Columbia University Press, 1986.

Dean, Carolyn. A Culture of Stone: Inka Perspectives on Rock. Durham: Duke University Press, 2010. Dosman, Edgar. The Life and Times of Raúl Prebisch, 1901-1986. Toronto: McGill-Queen's Press, 2008.

Friedrich Jörg and Ole Wæver. "Western Europe: structure and strategy at the national and regional levels". In International Relations Scholarship around the World, edited by Arlene Tickner and Ole Wæver, 261-285. London: Routledge, 2009.

Garcia, Beatriz. The Amazon from an International Law Perspective. Cambridge: Cambridge University Press, 2012.

Grandin, Greg. Fordlandia: The Rise and Fall of Henry Ford's Forgotten Jungle City. New York: Metropolitan Books, 2009.

Harris, Mark. Rebellion on the Amazon: The Cabanagem, Race, and Popular Culture in the North of Brazil, 1798-1840. Cambridge: Cambridge University Press, 2010.

Hecht, Susanna and Charles C. Mann. Where slaves ruled. National Geographic. 2012.

Hecht, Susanna. The Scramble for the Amazon and the Loss Paradise of Euclides da Cunha. Chicago: Chicago University Press, 2013.

Helliwell, Christine and Barry Hindess. The Past in the Present. Australian Journal of Politics of History 57(3)(2011): 377-388.

Henderson, Errol A. Hidden in plain sight: racism in international relations theory. Cambridge Review of International Affairs (26)(2013)1: 71-92.

Hobson, John M. The Eurocentric Conception of World Politics: Western International Theory 1760-2010. Cambridge: Cambridge University Press, 2012.

Inayatullah, Naeem. Autobiographical International Relations: I, IR. New York: Routledge, 2011. Jackson, Patrick Thaddeus. The Conduct of Inquiry in International Relations: Philosophy of Science and Its Implications for the Study of World Politics. New York: Routledge, 2011.

Maliniak, Daniel, Susan Peterson and Michael J. Tierney. TRIP Around the World: Teaching Research and Policy Views of International Relations Faculty in 20 Countries. Williamsburg: The Institute for the Theory and Practice of International Relations at The College of William and Mary, 2012. Mann, Charles C. 1491: New Revelations of the Americas Before Columbus. New York: Vintage Books, 2005.

Ogle, Vanessa. A Brief History of Time. 2015.

Raffles, Hugh. In Amazonia: A Natural History. Princeton: Princeton University Press, 2002.

Rostain, Stéphen. Islands in the Rainforest: Landscape Management in Pre-Columbian Amazonia.

Walnut Creek: Left Coast Press, 2013. 
Said, Edward W. The World, the Text and the Critic. Cambridge: Harvard University Press, 1983. Scott, James. Seeing Like a State: How Certain Schemes to Improve the Human Condition Have Failed. New Haven: Yale University Press, 1998.

Seth, Vanita. Europe's Indians: Producing Racial Difference, 1500-1900. Durham: Duke University Press, 2010.

Slater, Candace. Entangled Edens: Visions of the Amazon. Berkeley: University of California Press, 2002.

Tickner, Ann. "Retelling IR's foundational stories: Some feminist and postcolonial perspectives". Global Change, Peace and Security 23(1)(2011): 5-13.

Tickner, Arlene and David L. Blaney. Claiming the International. New York: Routledge, 2013. Tickner, Arlene and David L. Blaney. Thinking International Relations Differently. New York: Routledge, 2012.

Tickner, Arlene. "Core, periphery and (neo)imperialist International Relations”. European Journal of International Relations 19(2013): 627.

Tickner, Arlene. Latin American IR and the Primacy of lo práctico. International Studies Review 10(2008): 735-748.

Trouillot, Michel-Rolf. The Savage Slot. In Global transformations: anthropology and the modern world. New York: Palgrave, 2003.

Weinstein, Barbara. The Amazon Rubber Boom: 1850-1920. Stanford: Stanford University Press, 1983.

Whitehead, Neil L. Histories and historicities in Amazonia. Lincoln: University of Nebraska Press, 2003.

Wilkinson, Xenia V. Tapping the Amazon for Victory: Brazil's "Battle for Rubber" of World War II. Unpublished PhD dissertation, Washington, Georgetown University, 2009.

Wolf, Eric R. Europe and the Peoples Without History. Berkeley: University of California Press, 1982. Zimmerman, Andrew. "Africa in Imperial and Transnational History: A Multi-Sited Historiography and the Necessity of Theory". The Journal of African History 45(3) (2013): 331-340. 